\title{
Tragedy and Ecophobia: A Study of William Shakespeare's Macbeth and J.M. Synge's Riders to the Sea
}

\author{
Thakurdas Jana \\ State Aided College Teacher-I, Department of English, Bhatter College, Dantan, E-mail: \\ thakurdaso9o1@gmail.com
}

\begin{abstract}
Terry Eagleton's humorous question of "how a tragedy differs from a congress of global warming" echoes the tragic and traumatic life of human beings facing increasing violence of nature. In a tragedy, the protagonist does not have biophilia as conceptualized by Edward O. Wilson to explain the innate tendency of human beings to find connections with nature and other forms of life, rather experience with themselves of an ecophobia, 'antipathy towards nature' as defined by Simon C. Estok. In a tragedy, "the unfathomable agencies of Nature", to Eagleton, create ecophobia among the characters of tragedies written in most of the periods of literature. It is experienced in a Renaissance tragedy Macbeth by the Bard of Avon with the appearance of 'nature's mischief as well as in a modern tragedy Riders to the Sea by J.M. Synge with the destructive sea devouring Maurya's five sons, husband, and husband's father creating an antipathy towards nature as shown in Macbeth's fear of the 'unruly' and 'rough' night and the ambiguous movement of the Brinamwood, and Maurya's desperate request to resist Bartley to travel by sea to the Galway fair. Their ecophobia has created an unhinged personality among them. With all these perspectives this paper aims to re-establish a connection between ecophobia and tragedy and examine how ecophobia has been internalized among the characters of the aforementioned play.
\end{abstract}

Keywords: ecophobia, biophilia, tragedy, Macbeth, Shakespeare, Riders to the Sea, J.M.Synge.

In contrast with 'a soft inland murmur' of nature the violent 'thunder and lightning' cause tragedy in human life. The rude forms of nature like flood, acid rain, volcanic eruption, and other "biotic communities" create a sense of negativity among human beings towards nature resulting in the emergence of 'ecophobia' as conceptualized by Simon C Estok by extending the foundational work on 'material ecocriticism' by Serenella Lovino and Serpil Oppermann. Human beings' fear and hatred towards nature have loosened their 'biophilia', "the innate tendency to focus on life and lifelike processes" as defined by Edward O Wilson (1984, p.1). Biophilia persists human beings to "affiliate with the other forms of life" whereas "ecophobia' forces them to "confront our collective environmental error". According to Estok,

The ecophobic condition exists on a spectrum and can embody fear, contempt, indifference, or lack of mindfulness, (or some combination of these) towards the natural environment. While its genetic origins have functioned, in part, to preserve our specie, the ecophobic condition has also growth economies and ideological interests. . . Ecophobia exists globally on both macro and micro levels, and its manifestation is at times directly apparent and obvious but is also often deeply obscured by the clutter of habit and ignorance" (Estok, 2018, p. 1)

\footnotetext{
(C) AesthetixMS 2020. This Open Access article is published under a Creative Commons Attribution Non-Commercial 4.o International License (http://creativecommons.org/licenses/by-nc/4.o/), which permits non-commercial re-use, distribution, and reproduction in any medium, provided the original work is properly cited. For citation use the DOI. For commercial re-use, please contact editor@rupkatha.com.
} 
David Sobel in his book Beyond Ecophobia: Reclaiming the Heart in Nature Education (1996) defines ecophobia as "a fear of ecological problems and the natural world. Fear of oil spills, rainforest destruction, whale hunting, acid rain, the ozone hole, and Lyme disease" (p.5). This environmental tragedy or tragedy as a literary genre forecasting the violent forms of nature creates ecophobia among the general audience. The inherent connection between tragedy and ecophobia as invoked by Terry Eagleton with her humorous question on "how a tragedy differs from a congress on global warming" (Eagleton, 2002, p. 6) is found also in two very popular tragedies: Macbeth (First performed in 1606) by William Shakespeare and Riders to the Sea (pub. 1934) by J. M. Synge.

The beginning of Macbeth with 'thunder and lightning' and the appearance of the witches who "were thought capable of raising storms and had claimed to do so in News from Scotland (1591)" and that of The Riders to the Sea with the discussion over the sea's hovering up Michael's body between Cathleen and Nora arise fear towards nature. The witches in Macbeth, who 'look not like th' inhabitants o'th' earth' symbolizes disorder in nature as exemplified through not only 'thunder and lightning' but also 'fog and filthy air'. Estok observes that these 'wild, unearthly beings' are

...associated with the undecidable meteorological conditions of "so foul and fair a day" (1.3.38), the likes of which Macbeth has never seen... Macbeth's witches challenge the boundaries of the human through their associations with nature... (2011, p. 102).

In Riders to the Sea, Cathleen and Nora's discussion of Michael's dead body found in Donegal, and 'great roaring in the west' gives an impression of the ruthless sea 'refusing simple idealization of rural Ireland'.

To quote Estok, "Theorizing ecophobia means recognizing the importance of control" (p.5). But, it is truly ironic that 'the more control we seem to have over the natural environment, the less we actually have' (p.5). This unpredictability of the natural world has been experienced by the Elizabethan world with a shortage of food ${ }^{\mathrm{i}}$, a period of cold weather known as The Little Ice Age ${ }^{\mathrm{ii}}$, and a profound natural storm that has been an essence in Shakespearean tragedy. In Macbeth, this unpredictability is found in the sudden appearance of the witches in front of Macbeth and Banquo, their language, and these women like beings are 'associated with nature and, therefore, portrayed as wild and unpredictable as weather' as found in the line: "The earth has bubbles, as the water has,/ And these are of them. (Act 1, Scene 3, 1l. 79-80), and this 'human fears of hostile cosmos can be transformed into male fears about women' (Griffiths, 2006, p. 46-47) as found in Macbeth's fears of the 'instruments of darkness' (Act 1, Scene 3, 1l. 124) that would entice him into damnation:

If good, [the witches' predictions], why do I yield to that suggestion

Whose horrid image doth unfix my hair,

And make my seated heart knock at my ribs

Against the use of nature? Present fears

Are less than horrible imaginings.

My thought, whose murder yet is but fantastical,

Shakes so my single state of man

That function is smothered in surmise,

And nothing is but what is not. (Act 1, Scene 3, 11. 136-44) 
The unpredictability of the sea that Maurya affirms with the line "It's little the like of him knows of the sea ..." and of Maurya herself as found in her forgetting of giving a blessing to Bartley instead of "sending him out with an unlucky word behind him": Cathleen and Nora finds a deep unpredictability in the words of the mother to her son, as follows:

He's gone now, God spare us, and we will not see him again. He's gone now, and when the black night is falling I'll have no son left in the world. (n.p)

So, she is quite aware of the unpredictability and ruthlessness of the sea that eventually gallops her last son. This echoes the condition of the seafaring people and sea-side indigenous dwellers as narrated by Cait Johnson in his book Earth, Water, Fire, E Air (2006):

To seafaring people worldwide, with their generations of the drowned, the ocean can be a great, fierce cauldron where eater and eaten are boiled down together, an untamed and untamable presence. Sea-side dwelling indigenous people have long sought appease and control the implacable force of water with ritual offerings and ceremony, but, despite all human attempts at control and intervention, the sea remains, like deity, a Mystery. (Johnson, 2006, ch.5)

Estok argues that ecophobia is related to displacement, and voice. 'Displacement and repression' with 'unconscious anxiety' and 'avoidance' form one of the three stages of phobia formation following the Freudian hypothesis as found in his essay "The Unconcious" (1915). Again, in 1926 Freud's theory focused on "whether phobia is 'an inhibition or symptom' consisting of displacement and regression". Freud thought that human being's unconscious wishes and thoughts create unconscious conflict among id, ego, and superego. The unconscious conflict threatens the ego with the anxiety that it will overpower ego which may be unable to function as the entire ego's energy is used to deal with the anxiety. In this situation, the ego uses 'displacement' as a defense mechanism resulting in specific phobia. In Macbeth, Shakespeare uses 'displacement' as a key symbol 'in dramatizing the steady disintegration of the hero's world'. Shakespeare has probably drawn the horrid natural atmosphere and the witches as displacements to defend Macbeth's hidden desire of becoming the king of Scotland by any hook or crook. Macbeth's first speech in the drama: "So foul and fair a day I have not seen" (1.3.38) echoes the weird sisters' 'fair is foul' words suggesting that 'something has already happened before his entrance, that he has already been conjured', as confirmed by Nicholus Luke (2017). Simon Palfrey and Tiffany Stern also find the wired sisters of Macbeth as the wired sisters of Macbeth. The 'foul and fair' day 'already befuddles his categories of understanding' (2007, p.98). Macbeth by separating himself from his noblemen and other members of the court becomes indistinguishable in the natural world that must be cut away like unwanted weed at the end of the drama.

Ecophobia is central to the hostile geographies experienced by both the Elizabethan citizens in the early modern age with the beginning of colonialism and also the inhabitants of the Aran Island. Hostile geographies, according to Estok,

...house truculent, disenfranchised, and monstrous figures; and that such figures are on (and are often synecdochal of) the outside borders of decency and order. (Estok, 2011, p.15)

The witches killing swine like Macbeth and also Lady Macbeth who is often identified as the fourth witch in a patriarchal sense, instigating her husband to kill Duncan, and also the natural figures like the owl killing a falcon, cat 'Gray-Malkin', and 'Paddock' meaning a toad that are associated with the monstrous witches create hostile geography in Macbeth. Synge' drama has 
also presented the geographical hostility faced by the people of Aran Island as shown in the following conversation between Cathleen and Nora:

"Cathleen: Is the sea bad by the white rocks, Nora?

Nora: Middling bad, God help us. There's great roaring in the west, and it's worse it'll be getting when the tide's turned to the wind..."

But, amidst this atmospheric and geographical hostility, Bartley is to go to the situation that compels Nora to belief in the priest's words that ". . . Herself does be saying prayers half through the night, and the Almighty God won't leave her destitute". (n.p)

Cannibalism, a racial and environmental issue, is also a part of ecophobia following post-colonial ecocriticism. It transforms human beings into wild beasts and associates them with terrifying nature. Estok argues that

It is an ecophobic fashioning in that it offers a demonized geography that is to be both feared and despised. (Estok, 2013).

To support his hypotheses, he also quotes Stephen Selmon who argues that "the discourse of cannibalism "necessarily designates an absolute negation of 'civilized' self- fashioning in a place that is no place, and is always 'out there' '”'. (p.78) In Macbeth, Duncan's 'beauteous and swift' horses "turned wild in nature, broke their stalls, flung out/ Contending 'gainst obedience. ..." and also 'eat each other'. Before that "On Tuesday last/ A falcon towering in her pride of place/ Was by a mousing owl hawked at and killed." These cannibalistic behaviors of the horses and the owl symbolize Macbeth's usurping of Duncan i.e. his power and kingdom. Furthermore, the witches have cannibalistic power. According to Louise Montrose:

The cultural fantasy assimilates Amazonian myth, witchcraft, and cannibalism into an anticulture which precisely inverts European norms of political authority, sexual license, marriages practices, and inheritance rules. [...] in such Renaissance texts [e.g. Macbeth] is a mixture of fascination and horror (368). (qt. in Breit, 2019)

The sea in Riders to the Sea has also usurped all the sons Maurya with her husband and her husband's father as she mourns: "They're all gone now, and there isn't anything the sea can do to me. . . I'll have no call now to be up crying and praying when the wind breaks from the south. .." (n.p) This one-act tragedy elaborates, according to Ronan McDonald, "a pattern of response, a cultural structure through which profound loss is mediated and responded". This tragic pattern defines the relationship of the characters with nature and landscape. (Mathews, 17).

Again, ecophobia is the 'hallmark of human progress' whereas ecocriticism is defined with 'ecological humility' to use the term coined by Christopher Manes in his 1992 essay "Nature and Silence". Following anthropocentric claim of Bacon that natural elements are granted to human beings, Felipe Fernandez-Armesto in Civilizations: Culture, Ambition, and the Transformation of Nature (1999) argues that "civilization" is

...a process of collective self-differentiation from a world characterized implicitly or explicitly as 'barbaric' or 'savage' or 'primitive' By extension, societies judged to have achieved such self-differentiation are called “civilized." (Armesto, 1999, p.13)

Progress and the process of civilization have been synonymous to each other. But, both of them are also antagonistic to the non-human world. Development and the destruction of nature go hand by hand vanishing different biospheric elements from the earth and creating natural catastrophes that eventually result in ecophobia. Manes argues, 
If fungus, one of the 'lowliest' of forms on a humanistic scale of values, were to go extinct tomorrow, the effect on the rest of the biosphere would be catastrophic; in contrast, if Homo sapiens disappeared, the event would go virtually unnoticed by the vast majority of Earth's life forms. (Manes, 1992, p. 24).

Following Malcolm's order to 'Let every soldier hew him down a bough/ And bear't before him' (Act 5, Scene 4, 11. 4-5) the deforestation of Birnamwood might create a horror among the Elizabethan Londoners who experienced filthy air due to coal burning and deforestation that was restricted with Henry VIII's Act for the Preservation of Woods in 1543. But, "At the end of the sixteenth century, John Manwood was writing that "the greatest part of [forests] are spoiled and decayed" (*2), and by the seventeenth century, the concerns had become quite serious." (Estok, 2011, p.10)

Riders to the Sea has shown a family's constant negotiation with the ruthless sea, ardent weather, and infertile landscape of the Aran Island for the progress of the family. Instead of knowing the destructive power of the sea and the winds, both the sisters of Bartley allow him to travel by the sea to go to the Gallway fair to sell horses only for the development of the family though to Maurya ". . . what is the price of a thousand horses against a son where there is one son only?" This life of Bartley's family reflect as Synge felt,

...no personal complaint ... but seems to contain the whole passionate rage that lurks somewhere in every native of the island. In this cry the inner consciousness of the people seems to lay itself bare for an instant, and to reveal the mood of beings who feel their isolation in the face of a universe that wars on them with winds and seas. (qt. in Mathews,2009, p.17)

Like these popular tragedies, many forms of ecomedia have been articulating ecophobia for a long time. Estok argues that it

...probably has roots that reach back to the evolution of the opposable thumb, which enabled hominids to make tools and to conscript "wheat, barley, peas, lentils, donkeys, sheep, pigs, and goats about 9,00o years ago" (Estok, 2011, p.6).

This fear towards nature portrayed in a tragedy or created by the tragedy of human beings caused by a natural disaster has compelled the human world to control anything natural and to forget the romantic biophilia.

\section{Endnotes}

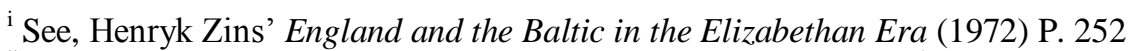

${ }^{\text {ii }}$ See, Jeffrey L. Forgeng's Daily Life in Elizabethan England-2 ${ }^{\text {nd }}$ ed. (2009) p. 125

\section{References}

Breit, Juliane. (2020). "Witchcraft in Shakespeare's Macbeth. Witches as Omniscient Prophets of Doom?". GRIN Verlag.

Clark, Sandra. \& Pamela Mason (ed). (2015). Macbeth. The Arden Shakespeare; London: Bloomsbury.

Eagleton, Terry. Sweet Violence: The Idea of the Tragic. New Jersey: Wiley-Blackwell, 2002. 
Estok, Simon C. (2018). The Ecophobia Hypothesis. London: Routledge.

- (2011). Ecocriticism and Shakespeare: Reading Ecophobia. New York: Palgrave Macmillan.

- (2013). "Cannibalism, E Cannibalism, Ecocriticism, and P cocriticism, and Portraying the Journe ying the Journey". 14(5). Purdue University

Fernandez-Armesto, Felipe. (1999). Civilizations: Culture, Ambition, and the Transformation of Nature. New York: The Free Press.

Freud, Sigmund. (1963). "The Unconscious (1915)". General Psychological Theory: Papers on Metapsychology. New York: Collier Books.

Griffiths, Emma. (2012). Medea. London: Routledge.

Luke, Nicholas. (2017). Shakespearean Arrivals: The Birth of Character. New York: Cambridge University Press.

Manes, Christopher. (1992). “Nature and silence”. Environmental Ethics 14 (4), p. 339-350.

Mathews, P.J. (ed.). (2009). The Cambridge Companion to J.M.Synge. Cambridge University Press.

McDonald, Ronan. (2002). Tragedy and Irish Literature: Synge, O'Casey, Beckett. New York: Palgrave Macmillan.

Palfrey, Simon. \& Tiffan Stern. (2017). Shakespeare in Parts. Oxford: OUP.

Sobel, David. (1996). Beyond Ecophobia: Reclaiming the Heart in Nature Education. USA: Orion Society.

Synge, Jon Millington. (1962). The Playboy of the Western World Riders to the Sea. London: Routledge.

Wilson, Edward O. (1984). Biophilia. Cambridge: Harvard University Press. 